\section{Managing schools as complex adaptive systems: A strategic perspective}

Tuncer Fidan ${ }^{a}$, Ali Balcı b

\begin{tabular}{ll}
\hline Received: & 29 March 2017 \\
Revised: & 22 August 2017 \\
Accepted: $\quad 12$ Sept. 2017 \\
ISSN: 1307-9298 \\
Copyright $\odot$ IEJEE \\
www.iejee.com
\end{tabular}

DOI: 10.26822/iejee.2017131883

\begin{abstract}
This conceptual study examines the analogies between schools and complex adaptive systems and identifies strategies used to manage schools as complex adaptive systems. Complex adaptive systems approach, introduced by the complexity theory, requires school administrators to develop new skills and strategies to realize their agendas in an ever-changing and complexifying environment without any expectations of stability and predictability. The results indicated that in this period administrators need to have basic skills such as (a) diagnosing patterns emerging from complexity, (b) manipulating the environment by anticipating potential patterns organizations may evolve into, (c) choosing organizational structures compatible with an ever-changing and complexifying environment and (d) promoting innovation to create and manage organizational changes. Although these skills enable administrators to reduce complexity into a manageable form to some extent, stakeholders' having a common perspective regarding their schools and environments, and executing their activities in accordance with a shared vision are required to turn these skills into complexity management strategies.
\end{abstract}

Keywords: Schools, complexity, complex adaptive systems, complexity management

\section{Introduction}

In the uncertain and constantly changing organizational environment of the information society, assumptions of order and predictability have gradually had a less part in administrators' lives, since the relationships and the course of events in social complex systems like schools are not linear. In school environments full of uncertainty caused by numerous connections and various options, administrators cannot diagnose potential problems and opportunities by using traditional methods. It is almost impossible to have control over a vast variety of results of organizational activities in an ocean of complex relationships. Therefore, it is a more proper approach to define schools as natural complex systems dominated by uncertainty, rather than as predictable ordered machines (Mennin, 2010; Daft, 2016). With the widespread interest in the open systems approach, this new understanding has become prominent in organization theory and given a new impulse to managerial studies (Lissack \& Gunz, 1999; Simon, 1962; Von Bertalanffy, 1950).

This conceptual study aims to discuss the analogies between schools and complex adaptive systems and to identify strategies used to manage schools as complex adaptive systems. The articles, working papers and books in English on organizations and complex adaptive systems published up to October 2016 were included and reviewed to elicit the strategies for managing complexity.

\section{Complexity}

It is a difficult challenge to define the term complexity because of different definitions in various disciplines.
Even scientists have not agreed on the definition of the term as complexity is a phenomenon arising from the interaction among numerous things (Johnson, 2007). Hence, it seems likely to develop a general definition for complexity such as self-organization of components in mutual interaction as hierarchical systems in order to build potential forms (Curlee \& Gordon, 2010).

The most widely used definition of complexity is the one developed by the Santa Fe group. According to this definition, complexity refers to an integrated and at the same time so rich and varied condition of the universe which we cannot comprehend in a usual mechanical way or in a linear fashion. It is of course likely to grasp many components of the universe through usual methods; however, broader phenomena having more complex interrelationships are likely to be understood only with the help of principles and patterns. Thus, complexity associates with emergence, innovativeness, learning and adaptation (Balcı, 2014; Sherman \& Shultz, 1998).

Complexity does not only refer to a number of moving components; on the contrary, it represents a system of components which interact mutually to the extent that it influences prospective events. Complex systems are composed of a number of interconnected components with characteristics such as self-organization, evolution and novelty (Lissack \& Gunz, 1999).

\section{Schools as Complex Adaptive Systems}

Organizations are open, social systems which endeavor to

\footnotetext{
a Corresponding author: Tuncer Fidan, Mehmet Akif Ersoy University, Office of Internal Audits, İstiklal Campus, 15030, Burdur/TURKEY. E-mail: tuncerfidan@gmail.com

${ }^{\mathrm{b}}$ Ankara University, Department of Educational Administration, Ankara/ Turkey, E-mail: alibalc@gmail.com
} 
survive in contemporary, unpredictable environments. Human resources, raw materials and financial sources provided by the environment are transformed to outcomes via technology. Complexity, in itself, associates with the number of different factors in external and internal environments that organizations are obliged to deal with at once. For this reason, the complexity of the environment and technology determines complexity level of organizations (Daft, 2016, 129; Scott, 2003, 230-233).

Simon (1962) holds hierarchical organizations up as examples of complex organizations. Hierarchy is a complex system built by interrelated sub-systems, however in modern organizations, the hierarchical perspective is not satisfactory to define complexity. Accordingly, Daft $(2016,18)$ mentions a three dimensional complexity; vertical, horizontal and spatial. Vertical complexity is the number of levels in a hierarchy while horizontal complexity means departments or professional expertises horizontally located in organizations. Spatial complexity associates with the geographical distribution of organizational departments or staff (Daft, 2016).

On the other hand, Scott (2003) suggests an institutional perspective to define complexity. According to Scott (2003, 230), tendency towards complexity can be examined at two levels: the first one is structural complexity of technical core of organizations and associates with the nature of daily organizational activities. This level is caused by the impact of technology on organizational structure. The complexity level of technical core increases as the variety of machines, information and methods employed to produce particular outcomes increases. Complexity observed in the technical core complexifies organizational structure by causing new units to emerge (Scott, 2003). The second level is the complexity of peripherical units at managerial and institutional levels apart from technical core. At this level, organizations start new units such as support staff and counselling to establish a buffer zone between their technical cores and environmental factors such as isomorphic pressures at sector level and to establish connections with other social institutions and organizations (Scott, 2003).

However, defining contemporary organizations merely by their complexity characteristics is restricted or even insufficient as it might cause us to consider organizations as reactive entities which only react to changes in internal and external environments. Contemporary organizations are dynamic adaptation and evolution systems that consist of various components interrelated with each other and their environments. Hence, it could be claimed that the main reason for complexity is the adaptation behavior of these components (Morel \& Ramanujam, 1999). In sum, defining contemporary organizations as complex adaptive systems seems more accurate (Holland, 2012).

The complex adaptive system is an approach built on the systems theory and it has taken over some characteristics such as emergence, connectivity, interdependence and dynamic feedback loops from that theory. Doubtlessly, the complexity approach has introduced new components to the systems theory and enriched organization studies by emphasizing relationships between those components (Mitleton-Kelly, 2003).

Like other organizations educational organizations exhibit characteristics of complex adaptive systems. At this point, Keshavarz, Nutbeam, Rowling and Khavarpour (2010) state that understanding schools as social complex adaptive systems may help education professionals to explain some of the challenges of starting and sustaining transformations in schools.

Complex adaptive systems like informal human architecture of a school are self-organizing entities. The systems without central control mechanisms are supposed to be dynamic and adaptive, not rigid and invariable. At this point, resistance of the term hierarchy appears, since it is unlikely to discuss a world without hierarchy when it comes to organizational structure. In this context, hierarchy in complex adaptive systems is almost inevitable to become shallow and flexible to allow a space for innovation efforts (Cilliers, 2001). This fact also leads complex adaptive systems away from Newtonian and Cartesian paradigm which assume that the natural condition of the system is equilibrium. Contemporary schools driven away from equilibrium to the edge of chaos might build new relationship patterns and different structures by being compelled to find out and try new opportunities (Fisher, 2006; Dooley, 1997; Mitleton-Kelly, 2003).

Self-organizing skills also reflect the development process of complex adaptive systems. The results obtained in this process depend on the past experiences, especially on the previous accidents (Holling, 2001). In other words, schools cannot escape from their past. They are deeply embedded in their external environment they interact with and the history of this interaction affects their development. When a choice is made in a complex environment, the direction of the future evolution (or later choices) of a school might depend on that critical choice (Tsoukas \& Dooley, 2011; Keshavarz, Nutbeam, Rowling and Khavarpour (2010). Moreover, tensions and alternative options emerged before the completion of the choice process on the edge of chaos could become sources of innovation and differentiation (Uhl-Bien, Marion \& McKelvey, 2007; Mitleton-Kelly, 2003).

Dependency on the initial conditions seen in complex adaptive systems requires the adoption of the principle of "path dependency", instead of "equifinality" principle of the systems theory. This tendency may bring an advantage in defining the obtained results. The "Butterfly Effect" has shown that initial conditions could have unique effects on nonlinear systems (Schneider \& Somers, 2006). In other words, irreversible processes may lead to different results under the same regulations, regardless of starting from similar initial conditions. Results depend not only on initial conditions but also on the past choices. In the long term, small, simple events may lead to outcomes influential on the whole system. This is why the path dependency can make predictions about the potential evolution of schools more complex (Mason, 2008). 
Contemporary educational organizations function in ecosystems that consist of networks with different degrees of connectedness and interdependence. In addition, these organizations are composed of units at different levels including individuals with complex relationship networks and different personal traits. Schools as complex adaptive systems are not capable of shaping the dynamics leading the whole ecosystem independently from others. In other words, they co-evolve together with other schools in the tangled web of mutual interactions. In the same way, mutual interactions between different organizational units or components coevolve together as well. A change in an entity can lead to a co-evolution by triggering a change in another interdependent entity (Breslin, 2014; Stead \& Stead, 2010).

On the other hand, the complexity theory asserts that complex adaptive systems can optimize their performance when they function as loosely interrelated network of mutually dependent components, or in other words, on the edge of chaos (Carroll \& Burton, 2000), since successful adaptation of the system depends on neither complete order nor complete disorder (Osborn \& Hunt, 2007). Nevertheless, in case of instability on the edge of chaos, long term outcomes of the system activities are unpredictable whereas the short term ones are predictable to some extent. For this reason, despite the provided opportunities, it is so difficult for schools to survive on the edge of chaos when compared to full stability or instability (Stacey, 1995) that even the most experienced administrators can have difficulties in predicting the future state of their organizations. In such cases, schools need to rely on skills of their members, especially those of administrators to anticipate potential scenarios regarding future trends in interorganizational environment (Hargreaves \& Goodson, 2006; Shaw, 1997).

\section{Managing Complexity}

Complexification of organizational life due to interlocked relationships and processes and rapid changes may create new units adding value to organizations, but at the same time, it causes non-value adding units to go unnoticed. What is worse is non-value adding activities can confuse organizational members and lead them to waste their time. Such activities may also distract employees' attention to trivial activities from the critically important ones for organizations. In short, increasing complexity may lead to ignore the forest or the big picture while being focused on specific trees (Collinson \& Jay, 2012).

Probably the most significant reason for such complexity is the diversification of students and their expectations. Therefore, "one-size-fits all" rule or a solution based on standard services approach does not meet the needs of the whole society. Also, the rich variety of legal regulations and state controls about production of educational services makes currently complex school work more tangled. Because the involvement of numerous actors such as parents, governments and teacher unions in the decision-making procedures adds new layers to organizational structures and processes. In this respect, complexity largely disrupts innovation skills of educational organizations and leaves them vulnerable to rapid changes (EIU, 2011; Hargreaves \& Goodson, 2006).

High environmental uncertainty poses certain questions about strategic management and strategic planning skills of educational administrators. How reasonable is to make short term plans, let alone the long term ones, when faced with mostly unknown, unpredictable future? However, one should not think that administrators are totally desperate in the face of complexity. Complexity could be considered as a playground which enables administrators to show their leadership skills and develops those skills with continuous testing. The playground full of sudden environmental shocks and uncertainty traps requires the development of a new strategic reference frame. Long term planning now gives way to more flexible, creative methods based on potential future scenarios regarding the course of organizational life while more detailed short term planning is already becoming shorter and it needs to be reviewed and readjusted regularly by means of data obtained from environmental scanning (Fidan \& Balcl, 2016; Haynes, 2015).

\section{Environmental Scanning}

It is getting more critical to apprehend educational organizations and relocate them to respond constantly emerging and vanishing social and technological trends as social life has become more uncertain and unstable. School administrators need to have skills to scan changes in their environment because of the uncertainty about the future of the number of students to be enrolled, methods and processes employed, teacher skills required and the results obtained in an ever-changing environment (Koberg, 1987).

The main difficulty the administrators face with reading the external environment is lack of information about organizational activities and interactions, which is caused by ever-changing, complex and dynamic business environment. Because administrators might not have developed skills to grasp clues about the current condition of their environments due to the uncertainty caused by complexity. Even if they have a chance to grasp the current condition of their environment, they may not foresee its potential influences on their organizations. Moreover they may not even know how to react to it when they notice it (May, Stewart, \& Sweo, 2000). At this point, Aguilar (1967; cited by El Sawy, 1985) suggests that environmental scanning can be employed to get information about events, trends and relations in an environment of a particular organization. The information gathered might then provide educational administrators with a chance to diagnose potential threats or opportunities in environments especially full of uncertainty and complexity (El Sawy, 1985).

Environmental scanning is an act which is directly carried out by both units created for this purpose and administrators themselves. In this process, both internal and external environmental resources can be used to obtain information. The former mainly includes databases on teachers and students, interpersonal connections and 
interactions and school activities and the latter on parents, teacher unions and other educational organizations, state policies, social media and similar more complex resources (Pashiardis, 1996). To illustrate, Shell Global BV has started a scenario team to scan the latest global political, economic and social occurrences and to develop potential future scenarios based on data obtained from such occurrences (Bentham, Khong, Schonfield \& Thomas, 2016).

The frequency of the environmental scanning behavior associates with the complexity level of organizational environment. As the complexity level increases, the frequency of scanning increases, as well (Daft, Sormunen \& Parks, 1988). Besides frequency, the form of scanning might vary according to the level of complexity. When administrators are faced with information overload caused by excessive complexity, scanning behavior generally takes place as passive scanning. Environmental scanning behavior occurs as reactive scanning when it is undertaken to seek solutions for the current issues. Additionally, there are more proactive forms of scanning with the aim of developing potential future scenarios such as random scanning used to monitor extraordinary resources and routine scanning used to monitor usual information sources (El Sawy, 1985).

At this point, particularly in the proactive environmental scanning process, the need for pattern recognition skills becomes apparent. Pattern recognition is to be able to diagnose patterns emerging from seemingly complex and irrelevant phenomena. Pattern recognition skill forms the basis of personal attempts to understand the environment and is critical especially for school administrators. Because many threats in the school environment become more severe as they cannot be early diagnosed, whereas many opportunities disappear before being identified (Baron, 2006; Dooley, 1997).

Pattern recognition is an effort which is carried out by individuals based on their cognitive frameworks acquired through personal experiences (Desoete \& Özsoy, 2009). Different models have been suggested to explain pattern recognition process. The first one, "prototype model" assumes that individuals act in accordance with the prototypes acquired through past experiences in pattern recognition. In this model, the fact that whether or not unexpected events or trends belong to specific cognitive categories of individuals or at least, they are associated with these categories is determined by the help of prototypes. For example, the cognitive framework of the term school enables us to understand the difference between schools and day care centers. In "exemplar model", another pattern recognition model, the knowledge of a specific example becomes prominent instead of ideal prototypes. Individuals compare unexpected events or trends they face with the knowledge of a specific past experience. In exemplar model, instead of building ideal prototypes, comparison of unexpected events or trends to the previously experienced ones takes place. To illustrate, experiences on marginal teaching and how to confront this problem serve as a useful sample pool to identify the causes of fluctuations in a school's academic performance (Baron,
2006). Within this framework, Anderson, Crabtree, Steele and McDaniel (2005) recommend that administrators focus on nonlinear features in the environmental scanning process, since revealing nonlinear patterns is a difficult and challenging task. Administrators should try to diagnose patterns in which small events lead to great results. What is more, it is essential not to overlook cases where big events result in small insignificant outcomes (Anderson et al., 2005).

What is more, administrators should try to notice unexpected events in the environmental scanning process. Focusing merely on outcomes may lead to ignoring useful behaviors and processes. Examining activities deviating from plans can provide deep information about a school and examining deviations from normality and routines can ensure understanding of a school's responses to complexity. Moreover, analyzing this kind of deviations can give administrators a chance to find out examples of creativity and improvement (Anderson et al., 2005; Marion \& Uhl-Bien, 2002).

The development of pattern recognition skills based on the past experiences, as one should remember, might make pattern recognition process problematic, since administrators could have a tendency to redo what they have done in similar cases in the past while making a decision in highly complex environments. However, the case encountered may be a far cry from the previous ones (Richardson, 2008). Administrators may not be able to clearly sort out emerging patterns, especially during major changes (Anderson, 1999). As a result, administrators should not expect the past issues to repeat identically and should avoid offering inflexible prescriptions previously developed for certain kind of problems in the past. Instead, they should try to understand what is unpredictable and unexpected (MacMillan, 2008) and take the framework of potential changes and pattern options into consideration (MacMillan, 2004). Because making choices regarding the organizational environment might give better results than attempting to directly influence emerging behavioral or interactional patterns (Lissack, 1999).

\section{Environmental Manipulation}

Besides scanning the observed environment to be adjusted with, complex adaptive systems are capable of influencing it. Managers of complex adaptive systems can change the environment to which system components will adapt and thus influence the progress and the variety of emerging potential behaviors (Simmons, Woog \& Dimitrov, 2007; Anderson, 1999). In a similar vein, large organizations in modern industrial societies are capable of manipulating their environments (Galbraith, 2007). Reactive or proactive response repertoires developed by educational administrators based on data from environmental scanning aim to change conditions in internal and external environments (Ford \& Baucus, 1987). Administrators may have the power to change the prevailing conditions in the environment where they function- the rules of the game, in other words. Even in some cases, top decision makers in educational organizations may have the chance to choose the environment they are going to operate in. For instance, 
educators might ignore or reduce certain topics in a given curriculum and union managers can change membership requirements (Child, 1972; Fidan \& Öztürk, 2015a).

However, unlike traditional stable and mechanical business life, information based, flexible components of the one in the information age do not allow administrators to plan the outcomes of their decisions and interventions in work procedures. The growth of interaction networks in and out-of-schools decreases the effectiveness of administrative controlling activities by causing an increase in the complexity of school life and in a matter of speaking, prevents the permanence of predictability isles that administrators have effortfully built (Mette, et. al., 2017). On the other hand, an increase in the interaction between school components and thus in a school's complexity positively influences creativity (Lissack, 1999; Rotmans \& Loorbach, 2009). In other words, making schools instable could carry them to the creativity zone on the edge of chaos (Walker, 1999). Administrators must foster order and disorder as the occasion arises by manipulating interactions between teachers or units, since a new order emerges from uncertainty on the edge of chaos (MacMillan, 2008) for the reason that emergence associates with the frequency of interactions between components. Besides that of complexity, the frequency and variety of emergence increase as interactions between organizations, groups and individuals increase (MacMillan, 2004).

According to Goldstein (1999), emergence means appearance of new, adaptive structures, patterns and characteristics in the self-organizing process. Emergence is not a characteristic of sub-units or teachers at micro level, but is a general characteristic of schools or an education system at the macro level caused by interactions between micro level components. While organizational components can separately be controlled, it is impossible to directly control the whole school or educational system. It is also unlikely to predict the results of the emergence process until it fully appears. When done completely, the emergence process transforms into a latter structure, pattern or feature due to its dynamic nature (Choi, Dooley \& Rungtusanatham, 2001; De Wolf \& Holvoet, 2004). Informal organizations are probably the most significant examples of emergence in organizational life as they are unpredictable structures spontaneously appear apart from officially dictated channels (Goldstein, 1999; Varadarajan, Clark, \& Pride, 1992).

The influence of informal organizations restricts the control power of administrators largely derived from formal rules. Hence, MacMillan (2004) advises administrators not to get desirable changes by controlling or directing individuals. On the contrary, people should be encouraged to find their own way (MacMillan, 2004). For example, Steve Jobs remarks it is necessary to show people their unnoticed needs rather than dictating them what to consume by the following statement: "Consumers need to be shown what they want" (Boni, Weingart \& Evenson, 2009). What is more, changes should take place through improvisation, not by rigid planning. Administrators must consider the current state of their schools as a transition to next state and need to be prepared for changing minds continuously because of the relentless nature of these transition processes (Anderson, 1999; Richardson, 2008). For instance, when faced with anti-smoking trends accelerated in the $80 \mathrm{~s}$, tobacco companies had to struggle with ever-changing and varying negative arguments and actions for a long time to maintain the tobacco market, and they mostly lost the war (Varadarajan, Clark, \& Pride, 1992). Then, leaving their previous positions, the companies headed for proactive, long term social strategies such as supporting projects for decreasing youth smoking and establishing humanitarian relief funds instead of replying negative arguments and actions one by one in order to recover their impaired credit and legitimacy (Metzler, 2001).

The given example indicates the importance of administrators' learning to live with disorder instead of resisting it. Educational administrators must avoid setting detailed, strict goals and patiently try to create the optimal environment for emergence. To this end, it is advisable to define few rules, obligations, goals and criteria in school activities and to create rapidly evolving teacher (or employee) teams (Anderson, 1999; Pounder, 1999). Complexity introduced by autonomous teams with less hierarchy and rules should be maintained until a new order emerges spontaneously (Grobman, 2005). When that kind of order emerges, the teams should be dismissed and complexity should be maintained (MacMillan, 2004) because disorders, despite uncomfortable and stressful, might be the part of transitions that schools need and offer administrators opportunities to introduce the desirable conditions or relationships. Eventually, transitions include creating new contexts by breaking the power of prevailing attractor patterns in favor of new ones (MacMillan, 2008).

\section{Reshaping Schools}

Contemporary organizations of the information age are complex adaptive systems seeking to adjust to environmental complexity. Organizational environment is a complex superior system including a great number of actual and probable events and relations. Organizations, with a need for immediate responses to an environmental complexity, prefer to decrease the number of layers between top executives and front line staff as their main strategy. The functions of sub-units that have to apply environmental complexity absorbing procedures have gradually become differentiated and varied (Boisot \& Child, 1999; Luhmann, 1994). In addition, large, centralized hierarchies have been replaced by more decentralized, horizontal organization forms because of the influence of information technologies, the urge for a decrease in fixed costs and the need for more flexible design of organizational operations (Öztürk \& Balcı, 2014). However, flatter organizational structures do not always provide advantages to organizations in complexity because as organizations have become more horizontal, control fields of top executives have expanded. Eliminating the positions of middle-level executives has led to the empowerment of sub-unit managers and they have become closer to top executives. Many organizations have entered into the process of new kind 
of centralization because of direct interactions between sub-units and top executives. On the other hand, the considerable delegation of decision-making authority to sub-units has caused particular procedures to become decentralized (Rajan \& Wulf, 2006). In the end, a structuring in which certain organizational units are simply, horizontally structured while some others are vertical and hierarchical has emerged instead of a structuring in which the overall organization becomes horizontal and hierarchies are totally removed. It has been observed that such a structuring is more advantageous for organizations in dealing with environmental complexity (Balcı, 2014). For instance, in 2011, Akio Toyoda, the president and CEO of Toyota Motor Corporation, suggested a new kind of organization in which the number of top and mid-level managers is lowered by $50 \%$ and extensive local units are empowered in order to increase their adaptability in local markets and allow innovations to emerge in local units (Porter \& Derry, 2012).

In a similar way, there have been researches with a claim that schools with more flexible organizational structures in which hierarchical structures are maintained to carry out one of the main functions like coordination on one hand, and horizontal structures are allowed in order to conduct complexity absorbing functions such as communication, innovation and creativity on the other could be more successful (Fidan \& Öztürk, 2015b). In these organizational structures, the following complexity absorbing strategies are found: (a) Setting different and conflicting goals at once as different sub-units have different functions, (b) undertaking various strategic activities to attain these goals, (c) decentralizing decision making processes and increasing interactions and connections within these processes. These strategies become more visible when schools develop procedures or small, autonomous teacher teams to facilitate information exchange. Although structures of these schools seem simpler than those of large hierarchical ones, mechanisms regulating exchange of information between sub-units and teachers are subject to more fluid and flexible rules. Hence, they are in fact more complex (Pearson \& Moomaw, 2005; Ashmos \& Duchon, 2000; Burton, Desanctis \& Obel, 2006).

Autonomous teams are particularly seen in organizations which operate in dynamic and complex environments. In those teams, the low number of flexible rules regulating interpersonal interaction facilitates information and resource flows. Those employees who are from different positions and professional backgrounds generally come together for innovation and each work outcome is unique. Those teams are usually temporary formations and are disbanded when their mission is completed. Direct administrative control does not lead to positive results as their tasks are unpredictable and complex. Therefore, coordination is generally provided by informal leaders or quasi-formal procedures. Decisions are not orders from top management, but are made through participatory governance (Balcı, 2014; Mintzberg \& McHugh, 1985).
Control based classical administrative strategies should not be expected to yield effective results in such cases where bureaucratic organizational dynamics do not apply because autonomous teams do not need administrators to control their goals and activities. They just need profound feedback and peer observation for self-control. In this case, administrators should abandon their previous roles of classical controllers and adapt themselves to new roles as coaches, mentors and client analysts and barrier removers. Providing coordination between teacher teams and administrators from different layers, and establishing communication with social stakeholders have been two of the prominent administrative roles seen in new kind of school structures. These roles indicate that school administrators have a key importance in establishing and maintaining social networks. Besides, they could have a facilitative role in solving interpersonal, intragroup and intergroup problems (Bozak, Yıldırım \& Demirtaş, 2011; Raelin, 2010).

A school structure consisting of autonomous teams requires empowering teachers and granting them more autonomy in their tasks. However, it is not possible to expect every teacher to embrace the empowering process in a positive way. Teams that are constantly formed and disbanded may cause teachers to pursue more organizational order and stability (MacMillan, 2004). Also, decisions are based on the current personal understandings although they are more reliable as they are made by a number of people just in self-governing teacher teams than those which are taken by a single individual. In a world characterized by constant changes, it is possible for people to have an already extinct world in their minds on which their own personal understandings are based (Jinyoung, 2017; Richardson, 2008).

\section{Promoting Creativity and Innovation}

Creativity and innovation can be considered among main life sources of organizations functioning in complex environments. Creativity and innovation are different concepts although they are sometimes interchangeably used. Creativity associates with the development of a new way of thinking, an invention or a solution while innovation is related with the application process of those things (Levitt, 1963; McLean, 2005). In a similar fashion, Amabile (1988) defines creativity, which the researcher considers a robust antecedent of innovation, as the production of new, practical ideas by individuals or small groups. Nevertheless, despite the enthusiasm it has caused, creativity has adverse side-effects on organizational order and stability (Dolan, Garcia \& Auerbach, 2003).

There are researchers who suggest that there is a strong relationship between complexity and creativity/innovativeness because of the pressure especially imposed by environmental uncertainty on schools. An increase in the number and variety of environmental factors with which schools have to deal makes the behaviors of those factors unpredictable. Organizations like schools operating in complex, unpredictable environments require more information in the decision-making process. As a result, when faced with environmental complexity challenges, educational 
organizations most typically respond in the following way as the chaos and complexity theory suggests: diversification of organizational forms and employee skills, or in other words, transformation into complex systems. Coalitions between teachers and employees at different sub-units, particularly in complex organizations having different functional sub-units at different levels, catalyze the development of new ideas by increasing the depth of the information produced. What is more, the presence of teachers and other employees with different areas of expertise nurtures innovation, introducing the production of different ideas. In sum, it is possible to describe creativity and innovation as conscious organizational responses to complexity, not as the side effects or outcomes of complexity (Anderson, 1999; Fidan \& Öztürk, 2015b).

At this point, it can be asserted that educational organizations need to be managed "on the edge of chaos" between order and chaos in order to become actually innovative. The edge of chaos is complex systems' maintaining a particular state of balance between order and chaos. During this state, the system neither is locked up at a point, nor dissolves when overwhelmed by uncertainty and over changeability. New ideas and innovations erode the edges of the status quo and make organizations instable. In this sense, the edge of chaos is a continuously shifting conflict zone between stagnation and chaos where systems can be adaptive and alive (Balcl, 2014; Stacey, 1995).

Schools can be disaggregated into interrelated smaller units such as autonomous teams in order to carry them to the creativity zone at the edge of chaos because teachers and other employees at these units may be able to develop more creative products when there is an increase in the complexity and difficulty levels of their tasks and they are managed with a flexible, supporting perspective instead of control based managerial strategies (Geraldi, 2008; Oldham \& Cummings, 1996). Also, autonomous teams consisting of personally and professionally heterogeneous teachers and employees could positively influence creativity (Pounder, 1999). Sundar Pichai, the CEO of Google, supports the idea with the following statement: "A diverse mix of voices leads to better discussions, decisions and outcomes for everyone" and he also points out that personal diversity must be critically important in all work procedures as well as innovative activities (Pichai, 2016). At this point, Goldstein (1994) claims questionings highlighting diversity could attract the system to the edge of chaos and thus to the potential crossroads, since emphasizing disagreements in work teams rather than agreements starts a real dialogue, raising cognitive patterns of employees to the surface (Dooley, 1997). However, these units should not be given too much autonomy to prevent schools from acting collectively. If this is the case, creative solutions to issues or innovations developed by a single unit can be employed in similar cases with which other units in interaction face and a whole school can co-evolve slowly in its natural course (Lissack, 1999).

Besides changing schools' organizational structures, administrators could employ various methods to promote creativity and innovativeness of teachers. For example, they can first define and shape contexts in which teachers interact to specify goals, problems and solutions to these problems. They can develop a vision focusing on long term outcomes rather than the short term ones and guide their staff to contribute to innovative work procedures. Moreover, school administrators can foster creativity and innovation by developing a school culture nurturing creative efforts and facilitating the flow of information. In this context, through intrinsic and extrinsic incentives, they can create a system that appreciates and rewards creative efforts (Jung, Chow \& Wu, 2003).

Although creativity and innovation are vital for educational organizations, previous achievements might restrict potential choices of a school and cause it to be caught unprepared for unpredictable turbulences of a complex environment. If achievements as a result of organizational evolution of schools based on innovations become taken-for-granted and institutionalized over time, school stakeholders can resist to changes more than ever. Adopting innovations previously useful for a school without questioning may cause "administrative blindness" and the developments on the horizon to go unnoticed. Therefore, it should not be forgotten that great achievements and overadjusting to successful innovations might restrict the range of strategies that could be employed by administrators in response to pressures caused by environmental changes (Richardson, 2008; Tushman \& O'Reilly, 1996).

\section{Modeling Complexity}

Cognitive models are deeply embedded assumptions, generalizations or images affecting the way people perceive the world and go into action. The power of cognitive models comes from their potential to affect people's actions. These models can also partially shape what is seen and perceived, that is, two individuals with different cognitive models may explain the same event in different ways as they attach importance to different details. One should recall this fact, at this point; no one can design a school in his/her mind as a whole. What is designed in mind is assumptions, stories and images regarding a school. Thus, with the help of cognitive models, school stakeholders can predict behaviors of a school as a whole and of other stakeholders and find clues about the underlying motives of these behaviors. Of course, stakeholders can have a chance to manipulate prospective behaviors of a school as a system in this way. On the other hand, unless school administrators build shared cognitive models, empowering teachers and other employees may cause an increase in organizational tensions and coordination loads of administrators (Halverson, Kelley \& Kimball, 2004; Senge, 1990; Bredeson, 1985).

Cognitive models can function as an instrument to decrease complexity in educational organizations that consist of highly decentralized separate units, by unifying different perceptions of environmental complexity. Also, organizations operating in different areas with numberless types of prevailing conditions could employ simplifying cognitive models to manage such complexity. 
To illustrate, during the petrol crisis in the 70s, company executives made great efforts to accept "stability, takenfor-granted assumption of previous decades, no longer prevails" and to mentally adapt to new business markets full of uncertainty (Senge, 1990). At this point, it is suggested that educational organizations decrease complexity by trying to understand and/or directly addressing it. In this way, it is possible to have the most appropriate model of complexity and to develop proper responses in accordance with that model. In other words, administrators should build cognitive models to simplify environmental complexity and enable school stakeholders easily make sense of organizational environment. Metaphor development could be considered an important stage in this process, because metaphors can provide stakeholders with a common language and thus facilitate expressing abstract concepts such as mission and strategy through ordinary words of daily language (Hill \& Levenhagen, 1995; Boisot \& Child, 1999).

It can be claimed that the reason for the appearance of metaphors is humans' weakness in the face of unpredictability. The basic conceptualizations aim at the simplification of complexity, since simplification can picture complexity as a controllable phenomenon. While doing this, one sees himself stronger than he actually is in the face of events beyond his control. As a result, most modeling aim at moving people away from the idea that they have little control on events around them (Mennin, 2010; Morgan, 2006).

In case of complexity, metaphors and other cognitive models could function as instruments to elaborate and explain the available information regarding school life, since they focus on similarities between events and make what is familiar more familiar (Oswick, Keenoy \& Grant, 2002). Besides, they could be employed to create new understandings for schools. Through those, the following can be provided: (a) School images, new ideas and information on organizational functioning of schools, (b) reflection of what is significant or not according to prevailing values, interests and shared understandings, (c) removing perceptual differences between administrators and teachers caused particularly by rapid changes and gathering stakeholders around a shared vision (Leech, \& Fulton, 2008; Morgan, 2001). For instance, considering schools as "organized anarchies" expresses both the unpredictability of organizational changes and the presence of different political actors with various interests and agendas in an attempt to get involved in management of these organizations only with two words (Simsek \& Louis, 1994).

Despite their effective capability of decreasing complexity, metaphors represent a biased and incomplete perspective since they emphasize a single feature of an organization, an event or a product while pushing others into the background or even ignoring them. For example, considering schools as machines has led to ignorance of the human side of organizations (Grady, Fisher \& Fraser, 1996; Morgan, 2006). In addition, a modeling based on a single metaphor or representation leads to overspecialization, which in turn decreases flexibility in dealing with external environmental complexity (Boisot \& Child, 1999).

At this point, Morgan (2006) suggests the use of different metaphors to describe different aspects of the current conditions and to explain how those differences can coexist. Similarly, Boisot and Child (1999) state that the incorporated use of different metaphors or cognitive models might provide convenience in comprehending conflicting representations of environmental complexity and developing different responses to each of these representations. This also causes a low level of specialization and enables educational organizations to operate flexibly when faced with environmental complexity. Doubtlessly, these reactions will not be completely adaptive to the environment but at least, the number of probabilities an organization can manage will increase (Boisot \& Child, 1999).

Shifting the focal point in cases where the use of different metaphors or cognitive models does not yield successful results in addressing multiple perspectives required by complexity may be useful. The use of different metaphors or modeling with administrators, teachers or students in the center can fill such a gap (Anderson et al., 2005).

\section{Developing and Sharing a Comprehensive Vision}

In the chaotic business world, where creativity and innovativeness break routines, employees are concentrated mostly in collaborative teams instead of vertical hierarchies and strict rules are replaced by flexible core principles, the traditional management perspective with top-down command-and-control styles of management has been losing its influence. Uncertainty of organizational boundaries and structures requires the development of new mechanisms to gather stakeholders on common grounds. In this context, it is stated that an administrative understanding which provides teachers with autonomy to make rapid decisions in case of sudden changes, and at the same time prevents them from losing their organizational membership by the means of the shared frame of reference can function as a stabilizer against environmental complexity (Marks \& Printy, 2003).

Although the nature of the shared frame of reference is expressed by administrators by using various terms such as vision, mission, organizational philosophy and set of core values, they all refer to the same thing: developing a comprehensive vision that directs school activities and communicate this vision to mobilize stakeholders (Morgan, 2013, 47). Vision is a cognitive model developed by a leader concerning the future state of a process, a group or an organization. Such cognitive models include numerous bits of information and build an ideal representation of what an organization will transform into in future (Zaccaro \& Banks, 2001). To illustrate, "The Army after Next" is the vision of the US Army about meeting the requirements of 2025 and beyond and developing strategies against future threats. The vision expressed in only three words is enough for people to build fictions in their minds about what an enormous organization will look like in the future (Adams, 2006). 
What is more, a vision shows the way that school stakeholders should follow out of uncertainty and surprises. Schools consist of different stakeholders with different backgrounds. Uncertainty may be at the highest level as these stakeholders make sense of school language, intentions and behaviors in various ways. Managing such a high level of complexity is only possible with developing a comprehensive, appealing vision that integrates different perspectives. In this sense, a vision arouses a feeling in all stakeholders that their lives and tasks are interrelated and carried out through widely accepted legitimate goals (Huffman, 2003; Lipton, 1996).

It does not seem right to leave vision development in educational organizations solely to the hands of administrators since it is essential to have a very large amount of information about functioning and culture of a school and needs and values of its stakeholders in order to develop a comprehensive, appealing vision. Moreover, a vision is not a sudden, instantly emerging image, but a model shaped by a long established process of discovery, discussion and improvement (Yukl, 2010). As it is seen, how likely is it for an administrator to have such a set of information and foresight? That is why; Senge (1990) indicates that a shared vision is one of the "learning organization" disciplines which he dubbed as "five disciplines". As a result, stakeholders should be encouraged to participate in vision development process. From this perspective, the following steps must be followed to develop a vision: (a) Involving key stakeholders in the vision development process, (b) identifying strategic goals widely accepted by school stakeholders, (c) identifying elements in the old ideology relevant to the new vision, (d) linking the vision with core competencies of the school, (e) assessing the credibility of the vision, and ( $f$ ) continually assessing the vision and making necessary improvements (Yukl, 2010).

As it is clear, a vision is a future model built on the old organizational ideology with the contributions of various stakeholders rather than an ideal created out of nothing. For example, Henry Ford's vision to produce an automobile for large masses of people evokes a broad spectrum of associations ranging from the picture of this goal concretized in some way to ideological tensions caused by the existing structure of the highly stratified class society. A vision can be considered as a strong compass, but it is essential that it should be communicated to and eventually internalized by all stakeholders in order to transform it into a complexity management instrument (O'Connell, Hickerson \& Pillutla, 2011).

Besides being communicated in written forms, school vision could be conveyed through personal communications. Many schools employ vision statements including a few sentences to communicate their visions. A vision can also be presented as a narration in which services are described at length in details from different stakeholders' perspectives in addition to a-few-sentence statements (Kose, 2010; Levin, 2000). Because whether written or oral, what is important here is a school's communicating where it aims to reach and what stakeholders can do to achieve this aim with such a clear and simple language that all stakeholders can easily understand (Lipton, 1996; O'Connell, Hickerson \& Pillutla, 2011). At this point, it can be stated that communication skills of administrators are a key means of sharing a vision as they represent their schools. Their words and actions include symbolic meanings beyond directives regarding daily, routine organizational behaviors; therefore, school administrators should make sure that their presences and activities convey right messages. For example, administrators strictly adhering to taken-forgranted routines in schools where innovativeness is an indispensable part of a school vision might evoke negative symbolic meanings. Especially in a classical hierarchical environment where the cost of speaking up innovative ideas is heavy, administrators should build up a new environment model in which stakeholders have a right to freedom of expression and develop reward mechanisms in order to break long established perceptions (Detert \& Edmondson, 2011). At this point, metaphors can be employed to communicate a vision to employees and to get them fully absorb it as metaphors can bring understandability by allowing the expression of complexity through simple terms.

Furthermore, the low number of hierarchical layers in educational organizations, direct communication between administrators and teachers, and administrators' being close to school functioning to the extent that they can apply direct strategies, follow the developments and control outcomes might facilitate vision sharing by all stakeholders. Accordingly, the direct interaction between administrators and stakeholders may be more influential on adoption of a vision by school stakeholders than the size of a school (Baum, Locke \& Kirkpatrick, 1998). Nevertheless, it should not be forgotten that there can always be unconvinced individuals no matter how perfect communication skills administrators have. In this case, administrators must focus on individuals who have not decided about the new school vision, yet (Farmer, Slater \& Wright, 1998).

\section{Discussion and Conclusion}

Administrators are generally trained to work in a stable world in which social roles are clear, individuals do not need to rebuild their lives over and over again and interpersonal interactions are guided by societal institutions through cultural patterns. In this context, an image of a stable world imposes the assumption of predictability of the future, interpersonal interactions and the results of changes as a prevailing way of thinking. This understanding causes administrators to develop strategies based on linear planning. However, these traditional, authoritarian and control based managerial strategies are certainly inefficient to cope with solving problems and managing changes and developments while dealing with the complexity, unpredictability and uncertainty of school environment and might even cause schools to face with a more instable and unpredictable environment (Berger \& Luckmann, 1995; Berger and Luckmann, 1991; Mason, 2007). In other words, it seems unlikely to define and manage a nonlinear, dynamic school environment by a linear, stable model (Burnes, 2005). 
Similarly, dividing administrative processes into hierarchical stages or sub-units with definite clear-cut boundaries, or in other words, dividing them into a series of rationally controllable parts would only be possible with a stable world image where administrators could choose the best way from a limited number of alternatives to attain a measurable, fixed goal. Unfortunately, it is impossible to freeze schools and stop their evolution in a world changing at an unprecedented pace (Burnes, 2005). As a result, although administrative procedures such as change, decision-making, etc. are theoretically divided into stages, boundaries between these stages or hierarchical sequencing become vague in practice (Armenakis \& Bedeian, 1999). Particularly, when specific concepts such as emergence, co-evolution, interdependence and dynamic feedback loops (Breslin, 2014; Mitleton-Kelly, 2003) derived from the complexity theory are considered, it seems more accurate to describe interrelationships between the complexity management strategies within a nonlinear, interlocking model (Figure 1), instead of a gradual, hierarchical model ranging from environmental scanning to school vision development.

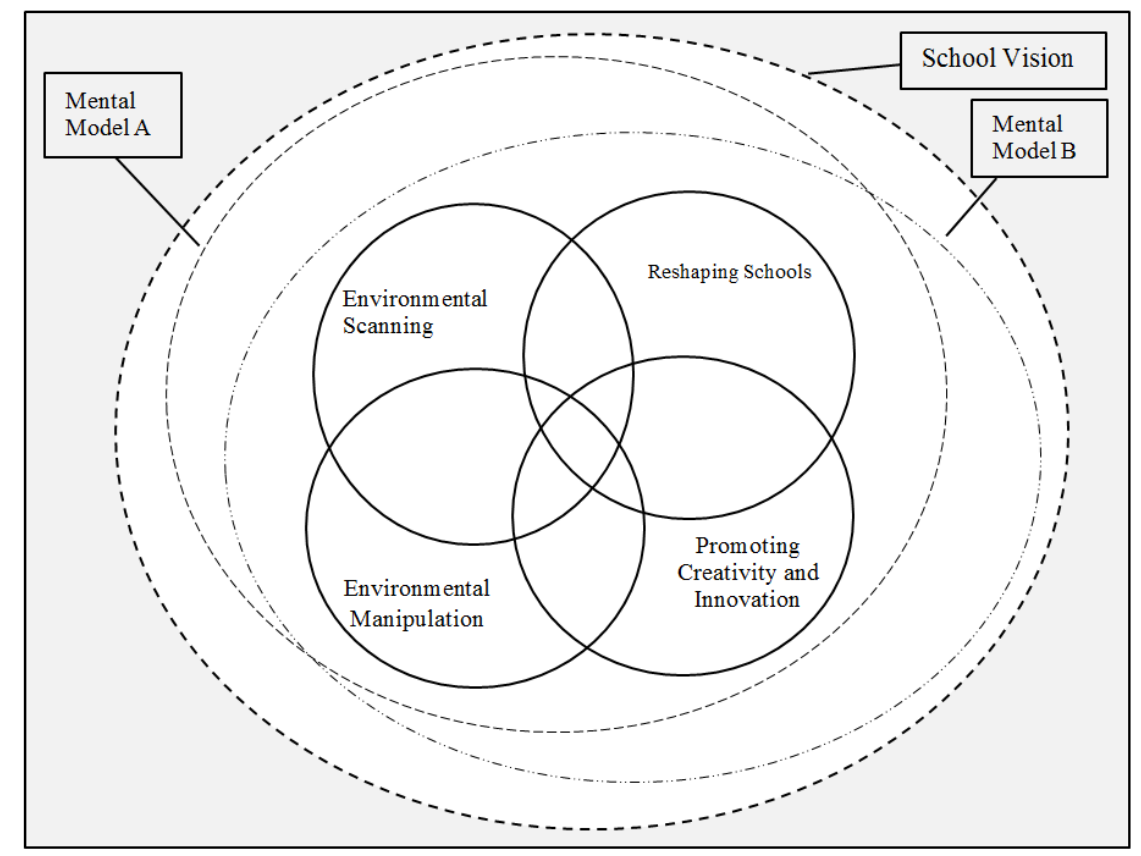

Figure 1. Interrelationships between complexity management strategies.

When Figure 1 is examined, it is seen that the strategies environmental scanning and manipulation, promoting personal creativity and innovativeness and reshaping schools are found in the center. When approached from the perspective of administrators, it is clear that the first strategy to be applied to manage environmental complexity is environmental scanning because exploring opportunities and pressures from internal and external environments such as sectoral regulations, legal requirements, demands of students and parents and teacher expectations provides critical clues about potential changes and strategic attempts to be made at adapting to environmental demands and manipulating school environments. Data obtained from the environmental scanning process not only ensure the adjustment between a school and its external environment, but also the application of proactive manipulation strategies such as social responsibility projects, political lobbying, new enrollment criteria, etc. to affect the environment in which a school operates (Lam \& Pang, 2003; Zeithaml \& Zeithaml, 1984). In addition, it is obvious that this kind of proactive scanning and manipulation strategies closely associate with the terms personal creativity and innovation, since environmental scanning is a motivating factor for innovations aiming at teacher empowerment to enhance personal creativity and improving capacity of an organization to intervene in internal and external environments. The increase in the information about the environment and in the technical capacity of a school leads, in turn, the greater expand in the capacity to adapt to environmental changes, and even in the capacity to create the desired changes. It can obviously be seen that it is a mutual relationship. In short, innovation and personal creativity might improve the variety, quality and consistency of environmental scanning activities as well as facilitating a school's interventions in its external and internal environments (Aragon-Correa \& Sharma, 2003). Naturally, the application of the above-mentioned strategies surely requires changes in organizational structures of schools, because the primary reaction of educational organizations to environmental complexity is restructuring in order to become more creative, entrepreneurial organizations. In this context, more flexible, horizontal structures consisting of small autonomous teams provide advantages in the production of new services in ever-changing environments (Lam, 2004, 4-5). Moreover, the restructuring of an educational organization could even be an innovative response, because an appropriate organizational structure is 
required for environmental scanning and manipulation, promoting creativity, and building and using innovation teams operating in more flexible structures with less formal rules and procedures (Aragon-Correa \& Sharma, 2003; Walker, 2008).

In Figure 1, it is also clear that the four strategies in the center are located on cognitive models. Because, school stakeholders could have a chance to make sense of complexity around their schools and interpersonal and interorganizational relationships emerging from that complexity by means of cognitive models. Shared cognitive models enable administrators to manage various, redundant information caused by complexity by simplifying environmental complexity. In this context, models regarding school categorizations indicate which type or scale of schools to be compared with by determining their positions relative to others (Tienken, Colella, Angelillo, Fox, McCahill, \& Wolfe, 2017). On the other hand, it is understood that the relationship between environmental scanning and cognitive models is mutual as data from scanning can be used not only to nurture the current models, but also modify them (Vandenbosch \& Higgins, 1996). In other words, beyond scanning the environment, cognitive models can be employed as robust instruments that can build school environment.

In this context, one might ask the following: "Can schools create their own environments in accordance with cognitive models to be developed for their environments?" "Yes" seems to be the probable answer to that question when cognitive models are shared by stakeholders and other educational organizations. Cognitive model development is a dynamic, long-term process constantly reshaped with the contributions of all stakeholders. They also take a long time to develop and include information of significant factors of school environment that one needs to know. This conceptual information may also provide stakeholders with new perspectives about how alternative forms of school structures could be (Trompenaars \& Hampden-Turner, 2011). For example, when a cognitive model that fosters innovativeness prevails in a classical, hierarchical structure, it might cause problems by interacting with the existing structure and forcing it to change towards a particular end. If compatible with the dominant mental model, an organizational structure can surely enhance the chance of success by reinforcing its power (Chen, Huang \& Hsiao, 2010; Bettis \& Prahalad, 1995). Similarly, an outward cognitive model attaching importance to individual differences can increase information production and create an ecosystem in which innovations can emerge. On the other hand, recently produced information might be influential on shaping the environment which is the source of prospective cognitive models of an organization (Davison \& Blackman, 2005; Garcia-Morales, Llorens-Montes, \& Verdú-Jover, 2006).

Cognitive models can fit the ways school stakeholders perceive and interpret their own schools and environments into a specific frame, but they may be insufficient to prompt stakeholders to act in accordance with potential future projections of schools. Then, a more robust instrument to ensure that is needed. Apparently, the complexity theory causes administrators to get bogged down. They need to encourage structural flexibility and innovation beyond building shared cognitive models in order to adapt to environmental complexity immediately. In this context, it is essential to empower teachers to increase personal creativity, and trust their skills to diagnose potential threats and opportunities. In addition, administrators have to intervene in internal and external environments of schools in order to create desirable changes. Necessary measures must be taken to prevent these strategies developed as a reaction to complexity from leading to more complexity. This is where school vision steps in, as it may canalize the attempts by various stakeholders into the point at which administrators would like to reach. Moreover, administrators must be able to prevent more complexity through cohesive application of different complexity management strategies towards a particular goal (Morgan, 2006; Nonaka, 1994).

Uncertainty and shocks caused by complexity lead to the emergence of new type of leadership by enabling administrators who apply these strategies to test their skills constantly. With that sense of leadership, administrators might play significant roles in carrying their schools to the edge of chaos, ensuring organizational learning and interacting with their environments, and hence in achieving adaptation (Boal \& Schultz, 2007). In other words, complexity becomes manageable by administrators' displaying proactive leadership behaviors, which is possible with the understanding of trends in school environments, the identification of potential fault lines and the inclusion of these data in action plans before facing any shocks. Briefly, administrators must provide against any conditions any time by anticipating changes instead of sitting and waiting for something to happen, and be able to foresee which strategies are going to be used predominantly in which cases (Fidan \& Balcl, 2016; Morgan, 2006).

In conclusion, the following might be asserted: Generally speaking, the leadership literature indicates that a notable progress has been made in complexity management particularly through studies on leadership traits required by complex adaptive systems (e.g. Morrison, 2010; Uhl-Bien, Marion \& McKelvey, 2007), but it is not likely to mention the same for strategy focused studies on complexity management. It is clear that the existing studies have mostly aimed to highlight theoretical similarities between real life organizations and complex adaptive systems with the help of the complexity perspective (e.g. Anderson, Issel \& McDaniel, 2003; Keshavarz, Nutbeam, Rowling \& Khavarpour, 2010). For this reason; in the future, further studies should focus on complexity management from a strategic perspective; within this scope, how these strategies will be influential on the development of administrative skills, what type of school leadership they require and how these school leaders play which roles emerge as subjects to be studied. Furthermore, the influences of strategies on educational organizations and their employees, and interrelationships between strategies are the subjects to be addressed by empirical researches. Additionally, how these strategies 
change in time according to variables such as culture, environment, school size, teacher and student profile and leadership skills of school administrators should be explored in detail in future research.

\section{References}

Adams, T. K. (2006). The army after next: The first postindustrial army. Greenwood Publishing Group.

Aguilar, F.J. (1967). Scanning the business environment. New York, NY: Macmillan Co. In El Sawy, O. A. (1985). Personal information systems for strategic scanning in turbulent environments: can the CEO go on-line? MiS Quarterly, 9(1) 53-60.

Amabile, T. E. (1988). A Model of creativity and innovation in organizations. Research of Organizational Behaviour. 10, 123-167.

Anderson, P. (1999). Perspective: Complexity theory and organization science. Organization science, 10(3), 216232.

Anderson, R. A., Issel, L. M., \& McDaniel Jr, R. R. (2003). Nursing homes as complex adaptive systems: relationship between management practice and resident outcomes. Nursing research, 52(1), 12.

Anderson, R. A., Crabtree, B. F., Steele, D. J., \& McDaniel, R. R. (2005). Case study research: the view from complexity science. Qualitative Health Research, 15(5), 669-685.

Aragon-Correa, J. A., \& Sharma, S. (2003). A contingent resource-based view of proactive corporate environmental strategy. Academy of Management Review 28(1), 71-88.

Armenakis, A. A., \& Bedeian, A. G. (1999). Organizational change: A review of theory and research in the 1990s. Journal of Management, 25(3), 293-315.

Ashmos, D. P., Duchon, D., \& McDaniel Jr, R. R. (2000). Organizational responses to complexity: the effect on organizational performance. Journal of Organizational Change Management, 13(6), 577-595.

Balcı, A. (2014). Managing on the edge of chaos. In S. Banarjee \& Ş. Ş. Erçetin (Eds.), Chaos, Complexity and Leadership 2012 (pp. 119-129). Springer Netherlands.

Balcı, A., \& Öztürk, İ. (2014).Türkiye'de eğitimin finansmanı ve eğitim harcamaları bilgi yönetim sistemine (TEFBiS) ilişkin okul yöneticilerinin görüşleri ve yaşadıkları sorunlar. Milli Eğitim Dergisi, 204(Güz), 63-86.

Baron, R. A. (2006). Opportunity recognition as pattern recognition: How entrepreneurs "connect the dots" to identify new business opportunities. The Academy of Management Perspectives, 20(1), 104-119.

Baum, J. R., Locke, E. A., \& Kirkpatrick, S. A. (1998). A longitudinal study of the relation of vision and vision communication to venture growth in entrepreneurial firms. Journal of Applied Psychology, 83(1), 43.
Bentham, J., Khong, C. O., Schonfield, J., \& Thomas, W. (2016). The Shell scenarios team. Retrieved August 10, 2016 from http://www.shell.com/energy-andinnovation/the-energy-future/scenarios/meet-theshell-scenarios-team.html.

Berger, P. L., \& Luckmann, T. (1991). The social construction of reality: $A$ treatise in the sociology of knowledge. London: Penguin Books Ltd.

Berger, P. L., \& Luckmann, T. (1995). Modernity, pluralism and the crisis of the meaning: The orientation of modern man. Gütersloch: Bertelsmann Foundation Publishers.

Bettis, R. A., \& Prahalad, C. K. (1995). The dominant logic: Retrospective and extension. Strategic Management Journal, 16(1), 5-14.

Boal, K. B., \& Schultz, P. L. (2007). Storytelling, time, and evolution: The role of strategic leadership in complex adaptive systems. The Leadership Quarterly, 18(4), 411 428.

Boni, A. A., Weingart, L. R., \& Evenson, S. (2009). Innovation in an academic setting: Designing and leading a business through market-focused, interdisciplinary teams. Academy of Management Learning \& Education, 8(3), 407-417.

Boisot, M., \& Child, J. (1999). Organizations as adaptive systems in complex environments: The case of China. Organization Science, 10(3), 237-252.

Bozak, A., Yıldırım, M. C., \& Demirtaş, H. (2011). An alternative method for professional development of teachers: Peer observation. Inonu University Journal of the Faculty of Education (INUJFE), 12(2), 65-84.

Bredeson, P. V. (1985). An analysis of the metaphorical perspectives of school principals. Educational Administration Quarterly, 21(1), 29-50.

Breslin, D. (2014). Calm in the storm: Simulating the management of organizational co-evolution. Futures, 57(2014), 62-77.

Burnes, B. (2005). Complexity theories and organizational change. International Journal of Management Reviews, $7(2), 73-90$

Burton, R. M., De Sanctis, G., \& Obel, B. (2006). Organizational design: A step-by-step approach. Cambridge: Cambridge University Press.

Carroll, T., \& Burton, R. M. (2000). Organizations and complexity: searching for the edge of chaos. Computational \& Mathematical Organization Theory, 6(4), 319-337.

Chen, C. J., Huang, J. W., \& Hsiao, Y. C. (2010). Knowledge management and innovativeness: The role of organizational climate and structure. International Journal of Manpower, 31(8), 848-870.

Choi, T. Y., Dooley, K. J., \& Rungtusanatham, M. (2001). Supply networks and complex adaptive systems: control versus emergence. Journal of Operations Management, 19(3), 351-366. 
Child, J. (1972). Organizational structure, environment and performance: The role of strategic choice. Sociology, $6(1), 1-22$.

Cilliers, P. (2001). Boundaries, hierarchies and networks in complex systems. International Journal of Innovation Management, 5(02), 135-147.

Coleman, Jr, H. J. (1999). What enables self-organizing behavior in businesses. Emergence, 1(1), 33-48.

Collinson, S., \& Jay, M. (2012). From complexity to simplicity: Unleash your organization's potential. New York, NY: Palgrave Macmillan.

Curlee, W., \& Gordon, R.L. (2010). Complexity theory and project management. Hoboken, NJ: John Wiley \& Sons.

Daft, R. L. (2016). Organizational theory and design (12th edition). Mason, $\mathrm{OH}$ : South-Western Cengage Learning.

Daft, R. L., Sormunen, J., \& Parks, D. (1988). Chief executive scanning, environmental characteristics, and company performance: An empirical study. Strategic Management Journal, 9(2), 123-139.

Davison, G., \& Blackman, D. (2005).The role of mental models in innovative teams. European Journal of Innovation Management, 8(4), 409-423.

Desoete, A., \& Ozsoy, G. (2009). Introduction: Metacognition, More than the Lognes Monster?. International Electronic Journal of Elementary Education, 2(1), 1-6.

Detert, J. R., \& Edmondson, A. C. (2011). Implicit voice theories: Taken-for-granted rules of self-censorship at work. Academy of Management Journal, 54(3), 461-488.

De Wolf, T., \& Holvoet, T. (2004). Emergence versus selforganisation: Different concepts but promising when combined. In Brueckner, S.A., Di Marzo Serugendo, G., Karageorgos, A.,Nagpal, R. (Eds.), Engineering selforganising systems (pp. 1-15). Springer Berlin Heidelberg.

Dolan, S. L., Garcia, S., \& Auerbach, A. (2003). Understanding and managing chaos in organisations. International Journal of Management, 20(1), 23.

Dooley, K. J. (1997). A complex adaptive systems model of organization change. Nonlinear Dynamics, Psychology, and Life Sciences, 1(1), 69-97.

EIU. (2011). The complexity challenge: How businesses are bearing up. A report from the Economist Intelligence Unit.

El Sawy, O. A. (1985). Personal information systems for strategic scanning in turbulent environments: can the CEO go on-line? MiS Quarterly, 9(1) 53-60.

Farmer, B. A., Slater, J. W., \& Wright, K. S. (1998). The role of communication in achieving shared vision under new organizational leadership. Journal of Public Relations Research, 10(4), 219-235.

Fidan, T., \& Balcl, A. (2016). Principal proactivity: School principals' proactive behavior forms and their levels of display. In Erçetin, Ş.Ş. (Ed.), Applied chaos and complexity theory in education (pp. 29-58). Hershey, PA: IGI Global.

Fidan, T., \& Öztürk, I. (2015a). Perspectives and expectations of union member and non-union member teachers on teacher unions. Journal of Educational Sciences Research- Eğitim Bilimleri Araştırmaları Dergisi, 2(5), 191-220.

Fidan, T., \& Öztürk, I. (2015b). The relationship of the creativity of public and private school teachers to their intrinsic motivation and the school climate for innovation. Procedia-Social and Behavioral Sciences, $195,905-914$

Fisher, T. (2006). Educational transformation: Is it, like 'beauty', in the eye of the beholder, or will we know it when we see it?. Education and Information Technologies, 11(3-4), 293-303.

Ford, J. D., \& Baucus, D. A. (1987). Organizational adaptation to performance downturns: An interpretation-based perspective. Academy of Management Review, 12(2), 366-380.

Galbraith, J.K. (2007). The New Industrial State. New Jersey, $\mathrm{NJ}$ : Princeton University Press.

Garcia-Morales, V. J., Llorens-Montes, F. J., \& Verdú-Jover, A. J. (2006).Antecedents and consequences of organizational innovation and organizational learning in entrepreneurship. Industrial Management \& Data Systems, 106(1), 21-42.

Geraldi, J. G. (2008). The balance between order and chaos in multi-project firms: A conceptual model. International Journal of Project Management, 26(4), 348356.

Goldstein, J. (1994). The unshackled organization. Portland, OR: Productivity Press.

Goldstein, J. (1999). Emergence as a construct: History and issues. Emergence, 1(1), 49-72.

Grady, N. B., Fisher, D. L., \& Fraser, B. J. (1996). Images of school through metaphor development and validation of a questionnaire. Journal of Educational Administration, 34(2), 41-53.

Grobman, G. M. (2005). Complexity theory: a new way to look at organizational change. Public Administration Quarterly, 29(3/4), 350-382.

Halverson, R., Kelley, C., \& Kimball, S. (2004). Implementing teacher evaluation systems: How principals make sense of complex artifacts to shape local instructional practice. In W. K. Hoy and C. G. Miskel (Eds.). Educational administration, policy, and reform: Research and measurement. (pp.153-188). Greenwich, CT: Information Age Publishing.

Hargreaves, A., \& Goodson, I. (2006). Educational change over time? The sustainability and nonsustainability of three decades of secondary school change and continuity. Educational administration quarterly, 42(1), 3-41. 
Haynes, P. (2015). Managing complexity in the public services (2nd edition). New York, NY: Routledge.

Hill, R. C., \& Levenhagen, M. (1995). Metaphors and mental models: Sensemaking and sensegiving in innovative and entrepreneurial activities. Journal of Management, 21(6), 1057-1074.

Holland, J. H. (2012). Signals and boundaries: Building blocks of complex adaptive systems. Cambridge, MA: The MIT Press.

Holling, C. S. (2001). Understanding the complexity of economic, ecological, and social systems. Ecosystems, 4(5), 390-405.

Huffman, J. (2003). The role of shared values and vision in creating professional learning communities. Nassp Bulletin, 87(637), 21-34.

Jinyoung, C. H. O. I. (2017). Understanding Elementary Teachers' Different Responses to Reform: The Case of Implementation of an Assessment Reform in South Korea. International Electronic Journal of Elementary Education, 9(3), 581-598.

Johnson, N. F. (2007). Two's company, three is complexity: A simple guide to the science of all sciences. London: Oneworld Pubns Ltd.

Jung, D. I., Chow, C., \& Wu, A. (2003). The role of transformational leadership in enhancing organizational innovation: Hypotheses and some preliminary findings. The Leadership Quarterly, 14(4), 525-544.

Keshavarz, N., Nutbeam, D., Rowling, L., \& Khavarpour, F. (2010). Schools as social complex adaptive systems: a new way to understand the challenges of introducing the health promoting schools concept. Social science \& medicine, 70(10), 1467-1474.

Koberg, C. S. (1987). Resource scarcity, environmental uncertainty, and adaptive organizational behavior. Academy of Management Journal, 30(4), 798-807.

Kose, B. W. (2010). Developing a transformative school vision: Lessons from peer-nominated principals. Education and Urban Society, 43(2), 119-136.

Lam, A. (2004). Organizational innovation. In J. Fagerberg, D. C. Movery \& R. R. Nelson (Eds.), The oxford handbook of innovation (pp. 115-147). Oxford: Oxford University Press.

Lam, Y. L., \& Pang, S. K. (2003). The relative effects of environmental, internal and contextual factors on organizational learning: the case of Hong Kong schools under reforms. The Learning Organization: An International Journal, 10(2), 83-97.

Leech, D., \& Fulton, C. R. (2008). Faculty perceptions of shared decision making and the principal's leadership behaviors in secondary schools in a large urban district. Education, 128(4), 630.

Levin, I. M. (2000). Vision revisited telling the story of the future. The Journal of Applied Behavioral Science, 36(1), 91-107.
Levitt, T. (1963). Creativity is not enough. Harvard Business Review. 41(3), 137-144.

Lissack, M. R. (1999). Complexity: The Science, its vocabulary, and its relation to organizations. Emergence, 1(1), 110-126.

Lipton, M. (1996). Demystifying the development of an organizational vision. MIT Sloan Management Review, 37(4), 83.

Lissack, M. R., \& Gunz, H. P. (1999). Introduction. In M. R. Lissack \& H. P. Gunz (Eds.), Managing Complexity in Organizations: A View in Many Directions (pp. 1-8). London: Quorum Books.

Luhmann, N. (1994). Modernity of science. New German Critique. Special Issue on Niklas Luhmann. 61, Winter, 923.

MacMillan, E. (2004). Complexity, organizations and change. New York, NY: Rotledge.

MacMillan, E. (2008). Complexity, management and the dynamics of change: Challenges for practice. New York, NY: Routledge.

Marion, R., \& Uhl-Bien, M. (2002). Leadership in complex organizations. The Leadership Quarterly, 12(4), 389-418.

Marks, H. M., \& Printy, S. M. (2003). Principal leadership and school performance: An integration of transformational and instructional leadership. Educational administration quarterly, 39(3), 370-397.

Mason, R. B. (2007). The external environment's effect on management and strategy: a complexity theory approach. Management Decision, 45(1), 10-28.

Mason, M. (2008). What is complexity theory and what are its implications for educational change?. Educational Philosophy and Theory, 40(1), 35-49.

May, R. C., Stewart, W. H., \& Sweo, R. (2000). Environmental scanning behavior in a transitional economy: evidence from Russia. Academy of Management Journal, 43(3), 403-427.

McLean, L. D. (2005). Organizational culture's influence on creativity and innovation: A review of the literature and implications for human resource development. Advances in Developing Human Resources, 7(2), 226-246.

Mennin, S. (2010). Self-organisation, integration and curriculum in the complex world of medical education. Medical education, 44(1), 20-30.

Mette, I. M., Anderson, J., Nieuwenhuizen, L., Range, B. G., Hvidston, D. J., \& Doty, J. (2017). The Wicked Problem of the Intersection between Supervision and Evaluation. International Electronic Journal of Elementary Education, 9(3), 709-724.

Metzler, M. S. (2001). Responding to the legitimacy problems of big tobacco: an analysis of the "people of Philip Morris" image advertising campaign. Communication Quarterly, 49(4), 366-381.

Mitleton-Kelly, E. (2003). Ten principles of complexity and enabling infrastructures In E. Mitleton-Kelly (Ed.), 
Complex systems and evolutionary perspectives on organisations: The application of complexity theory to organisations. Advanced series in management (pp. 2350). Oxford: Elsevier Science Ltd.

Mintzberg, H., \& McHugh, A. (1985). Strategy formation in an adhocracy. Administrative Science Quarterly, 30(2), 160-197.

Morel, B., \& Ramanujam, R. (1999). Through the looking glass of complexity: The dynamics of organizations as adaptive and evolving systems. Organization Science, 10(3), 278-293.

Morgan, G. (2006). Images of organization. Thousand Oaks, CA: SAGE Publications, Inc.

Morgan, G. (2013). Riding the waves of change: Developing managerial competencies for a turbulent world. Toronto: Imaginization, Inc.

Morgan, J. M. (2001). Are we "out of the box" yet? A case study and critique of managerial metaphors of change. Communication Studies, 52(1), 85-102.

Morrison, K. (2010). Complexity theory, school leadership and management: questions for theory and practice. Educational Management Administration \& Leadership, 38(3), 374-393.

Nonaka, I. (1994). A dynamic theory of organizational knowledge creation. Organization Science, 5(1), 14-37.

O'Connell, D., Hickerson, K., \& Pillutla, A. (2011). Organizational visioning: An integrative review. Group \& Organization Management, 36(1), 103-125.

Oldham, G. R., \& Cummings, A. (1996). Employee creativity: Personal and contextual factors at work. Academy of Management Journal, 39(3), 607-634.

Osborn, R. N., \& Hunt, J. G. J. (2007). Leadership and the choice of order: Complexity and hierarchical perspectives near the edge of chaos. The Leadership Quarterly, 18(4), 319-340.

Oswick, C., Keenoy, T., \& Grant, D. (2002). Note: Metaphor and analogical reasoning in organization theory: Beyond orthodoxy. Academy of Management Review, 27(2), 294-303.

Öztürk, İ., \& Balcı, A. (2014). Millî Eğitim Bakanlığının 652 sayılı kanun hükmünde kararname ile yeniden yapılandırılmasına ilişkin Ankara ili kamu ilkokul ve ortaokul yöneticilerinin görüşleri. Eğitim Bilimleri Araştırmaları Dergisi, 4(1), 213-241.

Pashiardis, P. (1996). Environmental scanning in educational organizations: uses, approaches, sources and methodologies. International Journal of Educational Management, 10(3), 5-9.

Pearson, L. C., \& Moomaw, W. (2005). The relationship between teacher autonomy and stress, work satisfaction, empowerment, and professionalism. Educational research quarterly, 29(1), 37.

Pichai, S. (2016). Google diversity. Retrieved August 11, 2016 from https://www.google.com/diversity/.
Porter, T., \& Derry, R. (2012). Sustainability and business in a complex world. Business and Society Review, 117(1), 33-53.

Pounder, D. G. (1999). Teacher teams: Exploring job characteristics and work-related outcomes of work group enhancement. Educational Administration Quarterly, 35(3), 317-348.

Raelin, J. A. (2010). The end of managerial control? Group \& Organization Management, 36(2), 135-160.

Rajan, R. G., \& Wulf, J. (2006). The flattening firm: Evidence from panel data on the changing nature of corporate hierarchies. The Review of Economics and Statistics, 88(4), 759-773

Richardson, K. A. (2008). Managing complex organizations: Complexity thinking and the science and art of management. Emergence: Complexity and Organization, 10(2), 13-26.

Rotmans, J., \& Loorbach, D. (2009). Complexity and transition management. Journal of Industrial Ecology, 13(2), 184-196.

Schneider, M., \& Somers, M. (2006). Organizations as complex adaptive systems: Implications of complexity theory for leadership research. The Leadership Quarterly, 17(4), 351-365.

Scott, W. R. (2003). Organizations: Rational, natural, and open systems (5th edition). Englewood Cliffs, NJ: Prentice-Hall.

Senge, P. M. (1990). The learning organization. New York, NY: Currency Doubleway.

Shaw, P. (1997). Intervening in the shadow systems of organizations: Consulting from a complexity perspective. Journal of Organizational Change Management, 10(3), 235-250.

Sherman, H. J., \& Schultz, R. (1998). Open boundaries: Creating business innovation through complexity. Reading, Massachusetts: Da Capo Press.

Simmons, B., Woog, R., \& Dimitrov, V. (2007). Living on the edge: A Complexity-Informed exploration of the human-water relationship. World Futures, 63(3-4), 275285.

Simsek, H., \& Louis, K. S. (1994). Organizational change as paradigm shift: Analysis of the change process in a large, public university. The Journal of Higher Education, 65(6), 670-695.

Simon, H. (1962). The architecture of complexity. Proceedings of the American Philosophical Society, 106(6), 467-482.

Stacey, R. D. (1995). The science of complexity: An alternative perspective for strategic change processes. Strategic Management Journal, 16(6), 477-495.

Stead, J. G., \& Stead, W. E. (2010). Sustainability comes to management education and research: A story of coevolution. Academy of Management Learning \& Education, 9(3), 488-498. 
Tetenbaum, T. J. (1998). Shifting paradigms: from Newton to chaos. Organizational Dynamics, 26(4), 21-32.

Tienken, C. H., Colella, A., Angelillo, C., Fox, M., McCahill, K. R., \& Wolfe, A. (2017). Predicting Middle Level State Standardized Test Results Using Family and Community Demographic Data. RMLE Online, 40(1), 1 13.

Trompenaars, F., \& Hampden-Turner, C. (2011). Riding the waves of culture: Understanding diversity in global business. London: Nicholas Brealey Publishing.

Tsoukas, H., \& Dooley, K. J. (2011). Introduction to the special issue: Towards the ecological style: Embracing complexity in organizational research. Organization Studies, 32(6), 729-735.

Tushman, M. L., \& O'Reilly, C. A. (1996). The ambidextrous organizations: managing evolutionary and revolutionary change. California Management Review, 38(4), 8-30.

Uhl-Bien, M., Marion, R., \& McKelvey, B. (2007). Complexity leadership theory: Shifting leadership from the industrial age to the knowledge era. The Leadership Quarterly, 18(4), 298-318.

Vandenbosch, B., \& Higgins, C. (1996). Information acquisition and mental models: An investigation into the relationship between behaviour and learning. Information Systems Research, 7(2), 198-214.
Varadarajan, P. R., Clark, T., \& Pride, W. M. (1992). Controlling the uncontrollable: managing your market environment. Sloan Management Review, 33(2), 39-48.

Von Bertalanffy, L. (1950). The theory of open systems in physics and biology. Science, 111(2872), 23-29.

Walker, N. (1999). Principals: Alive on the edge of chaos (An interview with Michael Fullan). The Ontario Principals Council Register: Magazine for Ontario's Principals and Vice-Principals, 1(6), 3-5.

Walker, R. M. (2008). An empirical evaluation of innovation types and organizational and environmental characteristics: Towards a configuration framework. Journal of Public Administration Research and Theory, 18(4), 591-615.

Yukl, G. (2010). Leadership in organizations (7th edition). Upper Saddle River, NJ: Prentice Hall.

Zaccaro, S. J., \& Banks, D. J. (2001). Leadership, vision, and organizational effectiveness. In Zaccaro, S.J. \& Klimoski, R. J. (Eds.), The nature of organizational leadership: Understanding the performance imperatives confronting today's leaders (pp. 181-218). San Fransisco, CA: Jossey Bass.

Zeithaml, C. P., \& Zeithaml, V. A. (1984). Environmental management: revising the marketing perspective. The Journal of Marketing, 48(2), 46-53. 